\title{
PENGARUH PENAMBAHAN HIDROKOLOID IOTA KARAGINAN UNTUK MENINGKATKAN KUALITAS, KEAMANAN DAN DAYA SIMPAN ROTI
}

\author{
[Effect of Iota-Carrageenan Hydrocolloids Addition on Improving Bread Quality, Safety and Shelf-life]
}

\author{
M. D. Ariyana*, S. Widyastuti, Nazaruddin, B. R. Handayani, W. Werdiningsih, \\ dan N. Rahayu \\ Program Studi Ilmu dan Teknologi PanganFakultas Teknologi Pangan dan Agroindustri Universitas Mataram
} *email: mutiadevi0705@gmail.com

\begin{abstract}
Bread is made and eaten in most countries around the world. Nowadays, the use of additives has became a common practice in the baking process to improve the bread quality. Nevertheless, addition of excessive artificial food additives have been linked to various health risks. Increasing in awareness of healthy food was stimulate various researches to found the food additives that safely used in the baking process, include the hydrocolloid which extracted from seaweed as the main commodity of West Nusa Tenggara. The aim of this work was to analyse the effect of iota-carrageenan extracted from Euchema spinosumaddition to improve the bread quality, safety and shelf-life during the storage periode. Up to date, no systematic study has been reported on the effect of iota-carrageenan as a natural food additive in the baking process. Based on the observation and experimental data, generally the addition ofiota-carrageenan was significantly affect the bread volume, elasticity, water content, crumb structure and texture, gas cell diameter and sensory parameter compared to the control. Iota-carrageenan at $0.4 \%$ concentration increased the bread volume by reduced the gas cell diameter that created the uniform matrix to prevent the gas lose during the baking process, same as the effect of bread improver addition. This level of consentration could also delayed the staling process by retarded the moisture migration to the surface that prevent the reduction of water content and elasticity during 96 hours storage of a bread. Sensory evaluation by a costumer panel gave the higher score for overall acceptability to the bread formulation added with iota-carrageenan compared to the control. The overall results showed that the iota-carrageenan potentially used as a natural bread improver to substituted the artificial food additives that widely used in baking process.
\end{abstract}

Keywords: bread, improver, iota carrageenan, shelf-life, food safety

\section{ABSTRAK}

Roti merupakan bahan makanan yang sangat banyak dikonsumsi di dunia. Saat ini, penambahan berbagai Bahan Tambahan Makanan (BTM) umum dilakukan untuk meningkatkan kualitas roti. Akan tetapi, penambahan BTMsintetis secara berlebihan dapat membawa berbagai konsekuensi kesehatan. Meningkatnya kesadaran akan pentingnya makanan sehat mengakibatkan semakin berkembangnya pencarian BTM yang aman pada proses pembuatan roti, salah satunya adalah hidrokoloid hasilekstraksi dari rumpul laut yang merupakan komoditas unggulan di provinsi NTB. Penelitian ini bertujuan untuk mempelajari pengaruh penambahaniota karaginan yang diekstraksi dari Euchema spinosumdalam meningkatkan kualitas, keamanan dan memperpanjang masa simpan roti. Saat ini belum ada laporan mengenai penggunaan iota karaginan sebagai BTM pada proses pembuatan roti. Berdasarkan hasil pengamatan dan data parameter yang diuji, penambahan iota karaginan pada adonan roti memberikan pengaruh yang signifikan pada volume pengembangan, elastisitas, kadar air, struktur dan tekstur crumb, diameter pori dan parameter sensoris roti.lota karaginan dapat meningkatkan persentase volume pengembanganterutama pada konsentrasi $0,4 \%$ dengan memperkecil diameter pori roti yang dihasilkan sehingga menciptakan suatu matriks yang seragam dan dapat bertindak sebagai perangkap untuk mencegah gas $\mathrm{CO}_{2}$ terlepas selama proses pemanggangan, serupa dengan pengaruhbread improver.Penambahan iota karaginan $0,4 \%$ juga memperlambat migrasi kelembaban menuju permukaan sehingga menghambat penurunan kadar air dan elastisitas roti hingga 96 jam masa simpan. Hasil uji organoleptik juga menunjukkan bahwa roti dengan penambahan iota karaginan lebih disukai. Peningkatan kualitas dan daya simpan roti dengan penambahan iota karaginan menunjukkan bahwa hidrokoloid jenis ini memiliki potensi untuk dikembangkan sebagai bread improver yang lebih terjamin keamanannya dibandingkan dengan bread improver sintetis yang saat ini digunakan dalam proses pembuatan roti.

Kata kunci: roti, pengembang, iota karaginan, daya simpan, keamanan pangan 


\section{PENDAHULUAN}

Roti telah menjadi salah satu makanan yang dikonsumsi oleh sebagian masyarakat setiap hari dan telah menjadi gaya hidup terutama untuk masyarakat di kota-kota besar sehingga kebutuhan masyarakat akan roti saat ini terus meningkat. Dengan meningkatnya jumlah penduduk dan pergeseran gaya hidup maka meningkat pula tuntutan akan roti baik dari sisi kuantitas maupun karakteristik organoleptiknya.Sebelum tahun 1950-an roti hanya dibuat dari bahan dasar tepung terigu, telur, gula dan ragi rotidengan proses fermentasi selama 24 jam sehingga terjadi fermentasi sempurna yang menghasilkan roti yang bernilai gizi tinggi dengan rasadan aromayang lezat.Namun produksi roti secara komersiil akan lebih mempertimbangkan aspek keuntungan dibandingkan denganaspek keamanan pangan.Berbagai jenis bahan tambahan makanan (BTM) diperlukan untuk mendapatkan roti yang memenuhi tuntutan konsumen.

Bahan tambahan makanan atau dikenal juga dengan istilah food additive yang biasa ditambahkan dapat berupa agensia pengembang, pemutih, pengoksidasi, pereduksi, enzim dan pengemulsi. Adapun penambahan bahan pengembang pada adonan roti (bread improver, bread developer, bread conditioner) ditujukan untuk dapat mempercepat proses produksi roti dengan mempersingkat waktu fermentasi dan mempercepat peningkatan volume adonan.

Terlepas dari status kehalalan BTM yang digunakan, beberapa produsen roti juga menambahkan BTM sintetis yang berbahaya bagi kesehatan konsumen diantaranya ialah potasium bromate (E 924) dan calcium propionate. Potasium bromate merupakan senyawa pengoksidasi kuat yang dapat ditambahkan pada adonan roti untuk memperkuat adonan dan meningkatkan volume crumb, sehingga dapat menghemat waktu dan biaya produksi. Akan tetapi, bahan ini sudah resmi dilarang penggunaannya di berbagai negara karena digolongkan ke dalam bahan kimia karsinogenik yang dapat memicu kanker oleh Enviromental Protection Agency (EPA). Di Indonesia, penggunaan bahan kimia ini untuk makanan juga dilarang berdasarkan Peraturan Menteri Kesehatan Nomor 033 Tahun 2012 Tentang Bahan Tambahan Pangan.Selain potassium bromated, produsen roti yang hanya mengejar untung besar tetapi tidak jujur seringkali menambahkan calcium propionat dengan takaran yang berlebihan sebagai penghambat pertumbuhan jamur sehingga dapat memperpanjang daya simpan roti. Yang mengkhawatirkan adalah konsumsi roti yang mengandung bahan kimia ini pada anak-anak dapat menimbulkan AttentionDefisit Hyperactivity Disorder (ADHD) yang menyebabkan seorang anak menjadi hiperaktif dan sulit berkonsentrasi.

Mengingat bahaya yang mengancam dibalik penggunaan BTM sintetis dan meningkatnya kesadaran akan produk makanan yang aman bagi kesehatan telah mendorong penelitian tentang potensi penggunaan bahan non sintetis pada proses pengolahan makanan. Beberapa pengolah roti tradisional menghindari penggunaan pengembang kimiawi, demi mempertahankan image sebagai produsen produk organik yaitu dengan menghindari penggunaan bahan kimia, seperti potasium bromate. Penelitian tentang potensi bahan tambahan alami atau non-sintetik yang aman serta dapat memperbaiki sifat adonan dan memperpanjang masa simpan produk roti juga telah mulai dilakukan. Salah satunya adalah penggunaan hidrokoloid. Penggunaan hidrokoloid dapat memperbaiki sifat adonan dan memperpanjang umur simpan roti dengan memperbaiki teksture (Rodge et al., 2012) dan meningkatkan kemampuan daya ikat air adonan (Mandala et al., 2007). Salah satu jenis hidrokoloid yang dapat digunakan adalah karaginan. Karaginan yang merupakan hidrokoloid hasil ektraksi dari rumput laut merah diketahui mempunyai sifat yang sangat baik untuk menahan air dalam bahan pangan (September, 2006). Menurut Rosel et al., (2001) karaginan memiliki karakteristik yang baik untuk digunakan sebagai bread improver karena dapat menghasilkan volume adonan yang lebih besar dan crumb yang lebih lembut. Keunggulan lain dari karaginan adalah hidrokoloid jenis ini mampu menghambat proses staling dan pertumbuhan jamur pada roti (September. 2007; Fennema, 1996; Sciarini et al., 2012).

Penelitian ini secara khusus bertujuan untuk mempelajari penambahan iota karaginan dalam proses pembuatan roti. Inovasi penggunaan karaginan sebagai BTM alami dalam pembuatan roti bermanfaat sebagai informasi ilmiah baik dalam berbagai pengajaran mata kuliah yang berhubungan dengan keamanan pangan dan juga bagi 
masyarakat pengolah pangan. Ketersediaan rumput laut jenis Euchema spinosum yang melimpah sebagai komoditi unggulan di Provinsi NTB juga memungkinkan penyediaan karaginan dalam jumlah yang memadai untuk dimanfaat sebagai BTM, sehingga tidak hanya menghasilkan produk roti yang aman dan memiliki daya simpan yang panjang tetapi juga mengembangkan potensi sumber daya lokal dan dapat meningkatkan perekonomian masyarakat.

\section{Bahan dan Alat}

\section{METODOLOGI}

Iota karaginan lokal diperoleh dari ekstraksi rumput laut yang dibudidaya di perairan Lombok yaitu Eucheuma spinosum. ahan penunjang dalam ekstraksi karaginan yaitu air, $\mathrm{NaOH}, \mathrm{HCL}$ dan isopropil alkohol. Bahan pembuatan roti diantaranya tepung terigu protein tinggi, gula, susu, kuning telur, ragi (fermipan), air, mentega dan garam.

\section{Pelaksanaan penelitian}

\section{a. Proses Ekstraksi Karaginan}

Ekstraksi iota karaginan dilakukan dengan metode ekstraksi panas dalam suasana basa dan pengendapan karaginan dilakukan dengan Isopropil Alkohol (IPA) sesuai dengan metode yang dilakukan oleh Handito (2011). Sampel rumput laut kering yang telah dipotong kecil direbus dengan air (1:40) selama 1 jam pada suhu $80-90^{\circ} \mathrm{C}$. $\mathrm{pH}$ larutan diatur dengan menambahkan larutan $\mathrm{NaOH} 0,1 \mathrm{~N}$ hingga $\mathrm{pH}$. Hasil ekstraksi disaring dengan kain saring bersih dan filtrat ditampung dalam beaker glass. Filtrate kemudian dituang ke wadah berisi cairan IPA (1:2) untuk diendapkan dengan cara diaduk 10-15 menit sehingga terbentuk endapan karaginan. Endapan karaginan ditiriskan dan direndam kembali dalam larutan IPA sampai diperoleh serat karaginan yang lebih kaku. Serat karaginan dibentuk tipis-tipis, diletakkan pada loyang kaca tahan panas, dikeringkan dalam oven pada suhu $40^{\circ} \mathrm{C}$ selama 12 jam

\section{b. Proses pembuatan Roti}

Dilakukan penimbangan semua bahan sesuai dengan komposisi yang telah ditentukan. Dilakukan pencampuran terigu, gula dan susu dengan bread maker menggunakan kecepatan rendah sampai tercampur rata. Masukkan ragi yang telah dilarutkan dengan air hangat dan kuning telur sedikit demi sedikit sambil diaduk sampai membentuk gumpalan-gumpalan. Setelah air tercampur, masukkan mentega dan adonan diaduk menggunakan kecepatan sedang hingga adonan kalis. Dilakukan fermentasi awal dengan cara membulatkan adonan dan ditutup plastik selama 30 menit. Adonan dikempeskan, ditimbang $70 \mathrm{~g}$, dan dibulatkan lalu dimasukkan ke dalam cetakan aluminium. Dilakukan fermentasi akhir dengan memasukkan adonan pada mesin proofer dengan suhu $30^{\circ} \mathrm{C}$ selama 1 jam. Pemanggangan dilakukan dengan suhu oven $180^{\circ} \mathrm{C}$ selama 20 menit.

\section{Rancangan Percobaan}

Penelitian dilakukan dengan rancangan acak lengkap yang terdiri dari satu faktor yaitu konsentrasi karaginan dengan lima aras yaitu $0 \%, 0,2 \%, 0,4 \%, 0,6 \%$ dan $0,8 \%$. Masing-masing perlakuan tersebut diulangi sebanyak tiga kali sehingga diperoleh 15 unit percobaan.

\section{Parameter uji}

\section{a. Volume pengembangan}

Volume roti diukur berdasarkan metode Hallen et al. (2004) dalam Aplevicz et al., (2013). Pertama roti sampel ditempatkan di dalam wadah yang telah diketahui volumnya (VC). Wadah kemudian diisi penuh dengan gabah, roti kemudian dikeluarkan dan volume gabah dalam wadah kemudian diukur (VR). Volume roti $(\mathrm{VL})$ diukur dengan persamaan:

$$
\mathrm{VL}(\mathrm{ml})=\mathrm{VC}-\mathrm{VR}
$$

Roti didinginkan selama 1 jam dan kemudian diukur beratnya W (g). Setelah itu, volume spesifik roti dihitung dengan persamaan:

$$
\mathrm{Vs}(\mathrm{ml} / \mathrm{g})=\mathrm{Vl} / \mathrm{W}
$$

\section{b. Kadar Air}

Metode untuk analisa kadar air yang digunakan dalam penelitian ini yaitu metode oven (thermogravimetri) (Sudarmaji dkk., 1997). Bahan yang telah dihaluskan ditimbang sebanyak $3 \mathrm{~g}$ dalam botol timbang yang telah diketahui beratnya. Dikeringkan dalam oven pada suhu $105^{\circ} \mathrm{C}$ selama 4 jam. Kemudian didinginkan dalam desikator selama 15 menit dan ditimbang. Dipanaskan lagi dalam oven 1 jam, didinginkan dalam eksikator dan ditimbang. Perlakuan ini diulangi sampai tercapai berat konstan (selisih penimbangan berturut-turut kurang dari 0,2 $\mathrm{mg}$ )Pengurangan berat merupakan banyaknya air dalam bahan:

$$
\begin{aligned}
& \text { Kadar air = berat awal-berat akhir/ } \\
& \text { berat awal x 100\% }
\end{aligned}
$$




\section{c. Uji Elastisitas}

Penentuan elastisitas roti selama masa simpan dilakukan berdasarkan metode Lazaridou, et al. (2007). Roti dipotong setinggi $3 \mathrm{~cm}$ dari dasar (t1). Permukaan atas roti kemudian ditekan dengan beaker glass hingga setengah dari tinggi semula $(1,5 \mathrm{~cm})$ selama 1 menit. Setelah 1 menit roti dilepaskan dan diukur tinggi roti (t2). Elastisitas roti dihiting dengan persamaan:

Elastisitas roti $=($ tinggi akhir $/$ tinggi awal) $\times 100 \%$

\section{d. Uji organoleptik}

Menggunakan uji hedonic dan uji scoring. Roti disajikan secara acak dengan kode tertentu. Kemudian panelis (25 orang) diminta untuk member penilaian terhadap rasa, tekstur, warna, aroma dan penampilan roti dengan kriteria yang telah ditentukan

\section{e. Uji masa simpan}

Uji fisik waktu terjadi stalling. Sampel disimpan pada suhu ruang dan diamati pada 0, 24, 48, 72 dan 96 jam dengan pengamatan mulai terjadi kekeringan bagian permukaan dan crumb (Lazaridou, et al.,2007).

\section{HASIL DAN PEMBAHASAN}

\section{Pengaruh Penambahan Iota Karaginan Terhadap Kualitas dan Daya Simpan Roti}

Penambahan iota karaginan pada adonan roti memberikan pengaruh yang signifikan pada seluruh parameter yang diuji meliputi volume pengembangan, elastisitas, kadar air, struktur dan tekstur crumb, diameter pori, rasa, tekstur dan warna roti. Penambahan iota karaginan dengan konsentrasi $0,4 \%$ menghasilkan roti dengan volume pengembangan terbaik (Gambar 1). Hasil pengamatan menunjukkkan bahwa penambahan iota karaginan hingga 0,4\% mampu meningkatkan volume pengembangan roti secara signifikan, sedangkan penambahan iota karaginan diatas $0,4 \%$ cenderung menurunkan volume pengembangan roti. Jika dibandingkan dengan kontrol, peningkatan volume pengembangan mencapai $50 \%$ pada penambahan iota karaginan $0,2 \%$ dan mencapai $100 \%$ pada penambahan iota karaginan $\quad 0,4 \%$. Peningkatan volume pengembangan menunjukkan adanya perbaikan struktur dan kestabilan adonan sehingga volume gas yang tertahan dalam adonan menjadi lebih besar. Menurut Raychaudhuri dan Chakraborty (2013), karaginan memiliki kemampuan dalam mempengaruhi jaringan atau pembentukan ikatan gluten dalam adonan sehingga dapat meningkatkan viskoelastisitas adonan. Peningkatan viskoelastisitas mengakibatkan pembentukan jaringan yang lebih stabil dalam menahan gas hasil fermentasi sehingga pengembangan roti lebih optimal.

Viskositas adonan yang terlalu tinggi cenderung akan menghambat pengembangan roti. Kondisi ini terjadi pada roti dengan penambahan iota karaginan $0,6 \%$ dan $0,8 \%$ yang mengalami penurunan volume pengembangan yang signifikan jika dibandingkan dengan roti dengan penambahan iota karaginan 0,4\%. Seperti yang dijelaskan oleh Peighambardoust et al. (2011) dan Lazaridou et al. (2007), penurunan volume pengembangan ketika menggunakan karaginan dengan konsentrasi yang lebih tinggi disebabkan oleh tingginya viskositas dan diikuti dengan adanya pembentukan fase gel yang menyebabkan adonan menjadi lebih kaku sehingga meningkatan resistensi adonan yang berakibat padalambatnya pengembangan dan perluasan pori selama prosesproofing dan pemanggangan. Viskositas meningkat secara eksponensial dengan konsentrasi (Stanley 1987dalam Winata 2008), ketika konsentrasi iota karaginan yang ditambahkan meningkat maka viskositas dan kemampuan membentuk gel pada adonan juga akan meningkat.

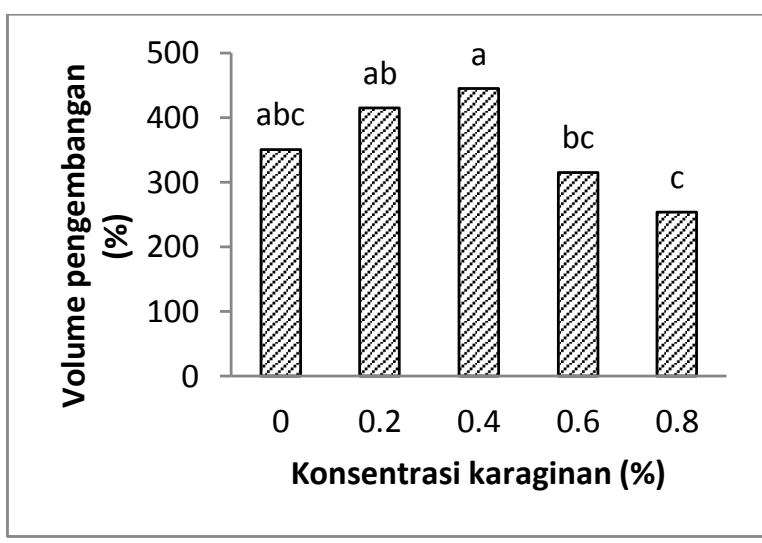

Gambar 1. Pengaruh Penambahan Iota Karaginan dengan Konsentrasi $0 \%$ $0,8 \%$ Terhadap Volume Pengembangan Roti

Pengaruh penambahan iota karaginan terhadap elastisitas roti menunjukkan pola yang sama dengan pengaruh penambahan iota karaginan terhadap volume pengembangan. Penambahan iota karaginan dengan konsentrasi $0,4 \%$ menghasilkan roti dengan elastisitas terbaikselama masa 
penyimpanan (Gambar 2). Hasil pengamatan menunjukkkan bahwa penambahan iota karaginan hingga 0,4\% mampu menjaga elastisitas roti hingga 96 jam penyimpanan, sedangkan penambahan iota karaginan diatas $0,4 \%$ cenderung menurunkan elastisitas roti. Jika dibandingkan dengan kontrol, penambahan iota karaginan $0,2 \%$ dan $0,4 \%$ dapat menjaga elastisitas roti cenderung lebih stabil hingga hari terakhir penyimpanan. Elastisitas roti dengan penambahan iota karaginan $0,2 \%$ dan $0,4 \%$ berkurang $20 \%$ setelah 96 jam penyimpanan, sedangkan elastisitas roti kontrol dan dengan penambahan iota karaginan $0,6 \%$ dan $0,8 \%$ berkurang hingga $30 \%$. Penurunan elastisitas terbesar terjadi dari hari ke-4 menuju hari ke5 atau setelah 96 jam penyimpanan, bahkan roti dengan penambahan iota karaginan 0,8\% mengalami penurunan elastisitas hingga $13 \%$.

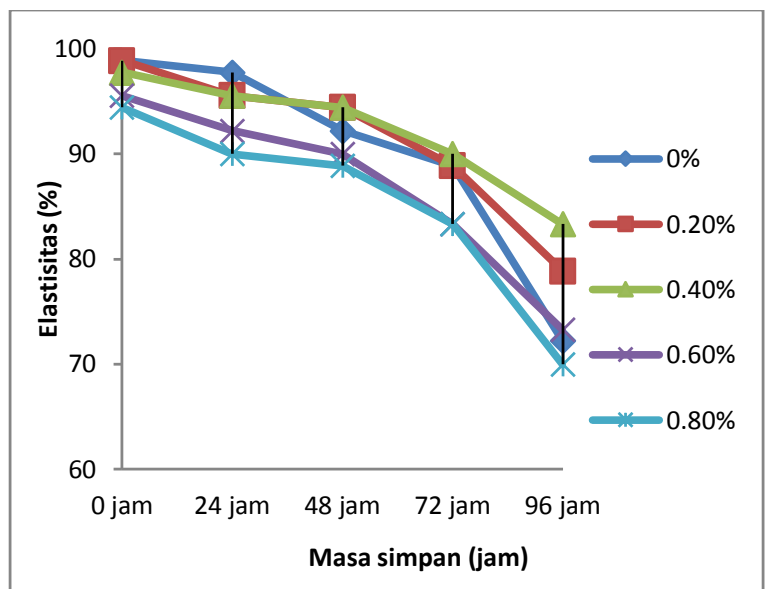

Gambar 2. Pengaruh Penambahan Iota Karaginan dengan Konsentrasi $0 \%$ - 0,8\% Terhadap Elastisitas Roti Selama 96 Jam Masa Simpan

Selain penurunan elastisitas roti, penurunan kadar air merupakan bukti lain terjadinya perubahan kualitas roti selama masa simpan. Berdasarkan data hasil pengamatan, roti dengan penambahan iota karaginan, memiliki kadar air yang lebih tinggi dan cenderung stabil selama masa simpan jika dibandingkan dengan kontrol (Gambar 3). Sharadanand and Khan (2003) dalam Raychaudhuri danChakraborty (2013) menyatakan bahwa secara umum roti dengan penambahan hidrokoid memiliki kadar air yang lebih tinggi. Hal ini menunjukkkan bahwa penambahan karaginan meningkatkan kemampuan adonan dalam mengikat air. Menurut Kahajdova dan Karovicova (2008) keberadaan gugus hidroksil pada struktur hidrokoloid memungkinkan adanya peningkatan interaksi dengan air melalui ikatan hidrogen.

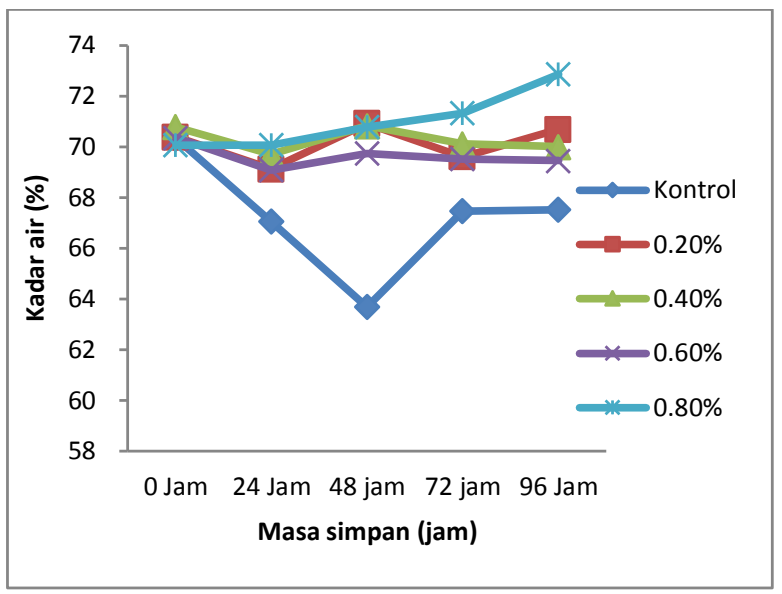

Gambar 3. Pengaruh Penambahan Iota Karaginan dengan Konsentrasi 0\% - 0,8\% Terhadap Kadar Air Roti Selama 96 Jam Masa Simpan

Stabilitas kadar air pada roti dengan penambahan karaginan, terutama dengan konsentrasi $0,2 \%$ dan $0,4 \%$, menjadikan roti dari kedua perlakuan ini cenderung dapat mempertahankan elastisitas selama masa simpan jika dibandingkan dengan kontrol. Kondisi yang serupa dilaporkan oleh Ghanbari dan Farmani (2013) yang menyatakan bahwa roti dengan penambahan hidrokoloid menunjukkan penurunan kadar air yang lebih rendah selama masa simpan sehingga menyebabkan berkurangnya laju dehidrasi pada crumb roti dan mencegah penurunan elastisitas roti. Kondisi yang berbeda terjadi pada roti kontrol, penurunan kadar air cukup tinggi selama masa simpan sehingga menyebabkan penurunan elastisitas yang cukup besar. Penurunan kadar air diketahui dapat mempercepat pembentukan ikatan silang antara pati dan protein yang menyebabkan roti menjadi keras dan tidak elastis (Raychaudhuri danChakraborty, 2013).

Pengamatan secara visual maupun melalui dokumentasi secara mikroskopis menunjukkan bahwa penambahan iota karaginan mempengaruhi struktur dan tekstur crumb serta diameter pori crumb. Hasil pengamatan menunjukkkan bahwa roti kontrol memiliki crumbyang cenderung kering dan keras, dengan pori-pori yang tidak seragam dan umumnya berukuran besar (Gambar 4 dan Gambar 5) . Hal ini dapat disebabkan oleh rendahnya viskositas adonan sehingga struktur adonan cenderung lemah dan berdampak 
pada pengembangan yang tidak optimal, pori - pori crumb yang tidak seragam dan kasar karena rendahnya kemampuan menahan gas.

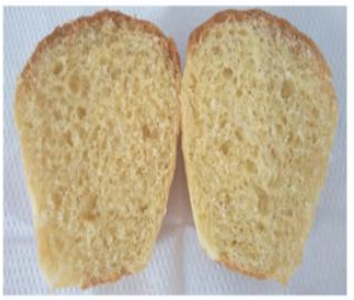

Kontrol (0\%)

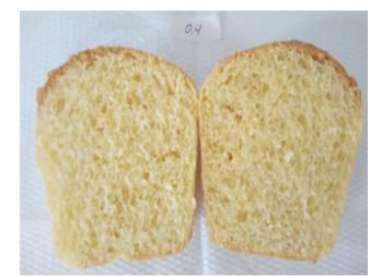

$0,4 \%$

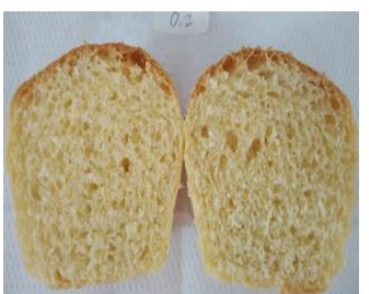

$0.2 \%$

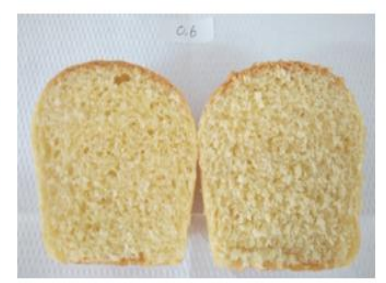

$0,6 \%$

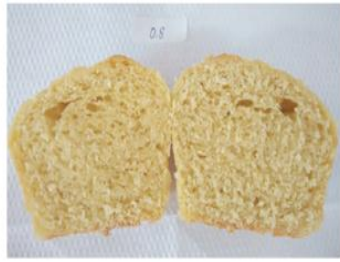

$0,8 \%$

Gambar 4. Penampang Crumb Roti Kontrol (0\%) dan Roti dengan Perlakuan Penambahan Iota Karaginan dengan Konsentrasi 0,2\% $0,8 \%$

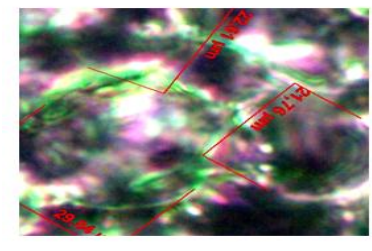

Kontrol (0\%)
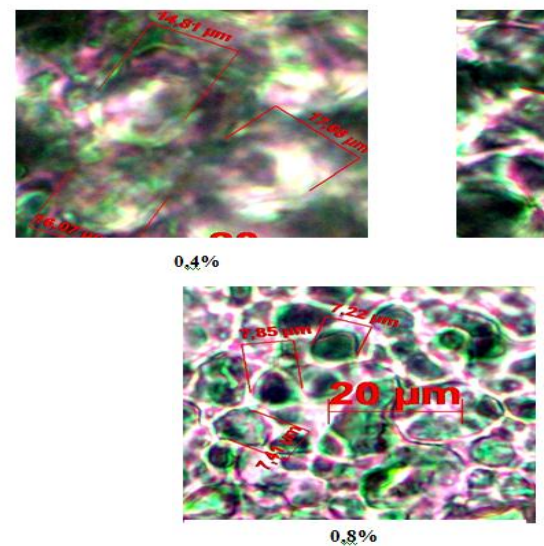

Gambar 5. Pori Crumb Roti Kontrol (0\%) dan Roti dengan Perlakuan Penambahan Iota Karaginan dengan Konsentrasi 0,2\%-0,8\%
Berbeda dengan roti kontrol, roti dengan penambahan iota karaginan memiliki crumb yang lebih lembab dan lembut, dengan pori-pori seragam dan memiliki diameter yang lebih kecil (Gambar 4 dan Gambar 5). Fakta ini didukung oleh pernyataan Raychaudhuri and Chakraborty (2013) yang mengemukakan bahwa penambahan hidrokoloid mencegah pori yang berdiameter kecil bergabung satu sama lain sehingga dapat menghambat pembentukan pori yang memiliki diameter lebih besar. Keberadaan pori berdiameter kecil dalam jumlah besar akan membantu menciptakan seatu matriks yang seragam dan dapat bertindak sebagai perangkap untuk mencegah gas $\mathrm{CO}_{2}$ terlepas selama proses pemanggangan. Hasil pengamatan crumb secara langsung maupun dengan bantuan mikroskop menunjukkan bahwa peningkatan konsentrasi iota karaginan mengakibatkan penurunan diameter pori crumb(Gambar 5).Efek serupa ditimbulkan oleh penggunaan improver yang dapat meningkatkan persentase volume pengembangan, tetapi memperkecil diameter pori roti yang dihasilkan (Hartajani dan Anjarsari, 2010). Semakin besar jumlah improver yang ditambahkan maka ukuran diameter pori roti yang dihasilkan semakin kecil dan jumlah pori yang dihasilkan semakin banyak.

Uji organoleptik yang dilakukan membuktikan bahwa penambahan iota karaginan berpengaruh secara signifikan terhadap rasa, tekstur dan warna roti (Gambar 6). Hasil uji menunjukkan bahwa roti dengan penambahan iota karaginan lebih disukai baik dari segi rasa, tekstur maupun warna, terutama roti dengan penambahan iota karaginan $0,6 \%$ dan $0,4 \%$. Dari segi rasa, roti dengan penambahan iota karaginan cenderung lebih gurih dan menonjolkan rasa khas dari roti. Dari segi tekstur, roti dengan penambahan iota karaginan memiliki tekstur yang lebih lembut serta lebih mudah dikunyah dan ditelan. Adanya perubahan warna akibat penambahan iota karaginan justru menjadi nilai tambah pada roti. Sedangkan dari segi aroma dan penampilan tidak terdapat perbedaan yang signifikan antara kontrol dan perlakuan.

Uji organoleptik juga menunjukkan bahwa masa simpan memberikan pengaruh yang signifikan terhadap rasa, tekstur dan warna roti. Hasil analisis menunjukkan adanya penurunan tingkat penerimaan panelis terhadap roti yang diuji seiring dengan bertambahnya masa simpan. 


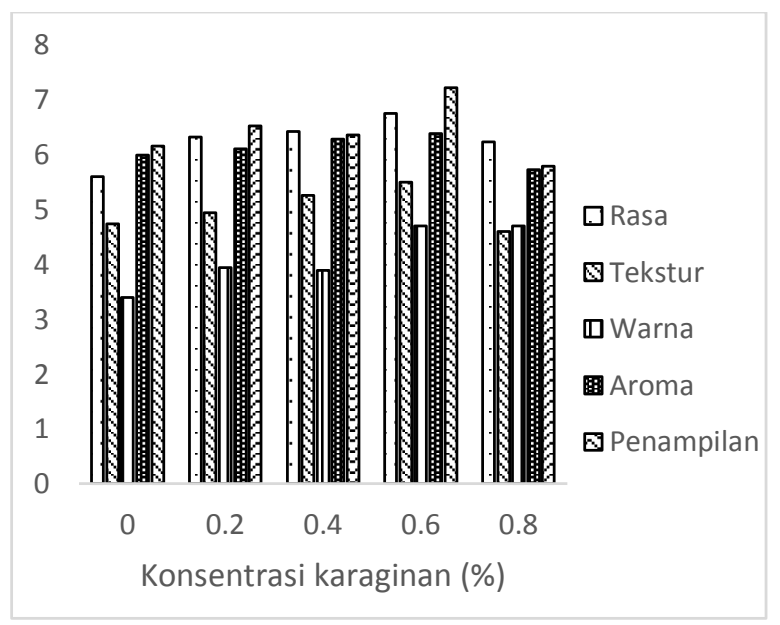

Gambar 6. Pengaruh Penambahan Berbagai Konsentrasi Iota Karaginan Terhadap Rasa, Tekstur, Aroma, Warna dan Tekstur Roti

*Data merupakan nilai rata-rata dari tiga ulangan

* Nilai rata-rata yang diikuti oleh huruf yang berbeda pada kolom yang sama menunjukkan berbeda secara signifikan $(\mathrm{P}<0.05)$

Potensi lain yang dimiliki karaginan sebagai BTM adalah kemampuan hidrokoloid ini menghambat pertumbuhan jamur pada roti selama masa simpan (September. 2007), sehingga dapat meningkatkan daya simpan roti yang umumnya sangat pendek. Akan tetapi, hasil penelitian ini belum dapat membuktikan adanya aktifitas antimikroba pada karaginan yang dapat memperpanjang daya simpan roti. Oleh karena itu, hal ini dapat menjadi masukan bagi penelitian selanjutnya.

\section{KESIMPULAN}

Iota karaginan menghasilkan roti dengan kualitas terbaik pada konsentrasi $0,4 \%$. Penambahan karaginan $0,4 \%$ mampu menghasilkan roti dengan volume maksimal, mempertahankan elastisitas dengan menghambat penurunan kadar air selama 96 jam masa simpan, menghasilkan crumb roti yang lembab dan lembut serta memiliki pori yang seragam dan berukuran kecil. Akan tetapi, dari segi rasa, tekstur dan warna, roti dengan penambahan karaginan 0,6\% cenderung lebih disukai. Untuk proses pembuatan roti dapat ditambahkan karaginan $0,4 \%$ hingga 0,6\%. Aktifitas antimikroba pada iota karagian belum dapat dibuktikan.

\section{DAFTAR PUSTAKA}

Aplevicz KS, Ogliari PJ, AnnaESS. 2007. Influence of fermentation time on characteristics of sourdough bread. Brazilian journal of Pharmaceutical Sciences. 49 (2).

Fennema. 1976. Principle of Food Science I. Food Chemistry. Marckel Dekker Inc, New York.

Gaman PM,Sherrington KB. 1992. Ilmu Pangan, Pengantar Ilmu Pangan, Nutrisi dan Mikrobiologi. Gajah Mada University Press, Yogyakarta.

Ghanbari M, FarmaniJ.2013. Influence of hydrocolloids on dough properties and quality of barbari: an iranian leavened flat bread. JAgr Sci Tech, 15: 545-555.

Handito D. 2011. Pengaruh konsentrasi karagenan terhadap sifat fisik dan mekanik edibel film. Agroteksos, 21:2-3.

Kohajdová Z, KarovicováJ.2008. Influence of Hydrocolloids on Quality of BakedGoods. Acta Sci. Pol., Technol. Aliment. 7(2): 43-49

KurokawaY, Maekawa

A, Takahashi,HayasiMY.1990. Toxicity and carcinogenicity of potassium bromate; a new renal carcinogen. Environ Health Persp87:309-335.

LazaridouA, DutaD, PapageogiouM, Belc $\mathrm{N}$,BiliaderisGC. 2007. Effects of hydrocolloids on dough rheology and bread quality parameters in gluten-free formulation. J of Food Engineering, 79:1033-1047.

Leon AE, Ribotta PD, Fernandez C, Lanada CA, Beltramo DM. 2000. Interactions of different carrageenan isoforms and flour components in breadmaking. J Food Agric Food Chem, 48 (7): 2634-8.

Raychaudhuri DL, ChakrabortyR. 2013. Role of hydrocolloids in improving the physical and textural characteristics of fennel bread. International Food Research Journal, 20(5): 2253-2259.

Rodge $A B$, Sonkamble SM, Salve RV, Syed IH. 2012. Effect of Hydrocolloid (Guar Gum) Incorcopration on the Quality Characteristics of Bread. J Food Process Technol, 3:2.

Rosell CM, RojasJA, Benedito C. 2001. Influence of Hydrocolloids on Dough Rheology and Bread Quality. Food Hydrocol, 15: 75-81. 
Salim-ur R, Ahmed, Mudassar. 2003. Effect of carboxy methyl cellulose and carrageenan gum on the shelf life of bread. Pak J Food Science, 13(1): 49-52

Sciarini LS, Ribotta PD, Leon AE, Perez GT. 2012. Incorporation of several additives into gluten free breads: effect on dough properties and bread quality. J Food Eng, 111: 590-597.

Selomulyo VO, Zhou W. 2006. Frozen Bread Dough: Affects of Freezing Storage and Dough Improvers. J of Cereal Science. Elsevier Ltd.
September C. 2007. The Effect of Enzymes, Gums and Proteins on the Water Absorption, Loaf Volume and Shelf Life of Bread. Master thesis. Univ. Johannesburg oct

Sudarmaji S, Haryono B, Suhardi. 1997. Prosedur Analisa untuk Bahan Makanan dan Pertanian. Liberty, Yogyakarta.

Zlatica K, Jolana K, Štefan S. 2009. Significance of Emulsifiers and Hydrocolloids in Bakery Industry. Acta Chimica Slovaca, Vol.2, No.1, 2009, 466. 